\title{
Spontaneous development of lung adenocarcinoma in the CADM1 gene-deficient mice
}

\author{
Masayoshi Nagata', Mika Sakurai-Yageta', Daisuke Yamada', Taketo Kawai', Yumi Tsuboi', Takeshi Ito', \\ Akihiko Ito ${ }^{1}$, Midori Yoshida ${ }^{2}$, Yoshinori Murakami ${ }^{1 *}$ \\ From 16th International Charles Heidelberger Symposium on Cancer Research \\ Coimbra, Portugal. 26-28 September 2010
}

\begin{abstract}
Aberration of cell adhesion is a critical step in the development and progression of human tumors. A tumor suppressor gene, CADM1(Cell adhesion molecule 1)/TSLC1(Tumor suppressor in lung cancer 1), was originally identified in non-small cell lung cancer (NSCLC) by its tumor suppressor activity in nude mice. CADM1 encodes an immunoglobulin superfamily cell adhesion molecule which is expressed in the brain, testis, lung and various other epithelial tissues. In normal polarized epithelia, CADM1 is expressed along the lateral membrane and associates in the cytoplasm with a member of 4.1-family proteins carrying actin-binding activity. On the other hand, CADM1 is inactivated by loss of the chromosomal fragment and/or methylation of the gene promoter in $30-60 \%$ of various human cancers, including NSCLC. To understand the physiological roles of CADM1, we have generated Cadm1/Tslc1 gene-deficient mice and have found that Cadm1-/- male mice are infertile due to the disruption of cell adhesion between the immature spermatocytes and Sertoli cells.
\end{abstract}

Here, we demonstrate that more than $30 \%$ of Cadm1-/- mice developed lung adenomas or adenocarcinomas spontaneously at 15 months of age. In the tumors, normal alveolar structure was completely replaced by the tumor cells with atypical nuclei. Lung tumors also developed in Cadm1+/- mice at 18 months of age through the second hit of the Cadm1 gene, indicating that CADM1 cascade is critical to lung tumor suppression. Immunohistochemical study revealed that the membrane localization of $4.1 \mathrm{~N}$ and CADM4,

\footnotetext{
* Correspondence: ymurakam@ims.u-tokyo.ac.jp

'Division of Molecular Pathology, Institute of Medical Science, The University of Tokyo, Tokyo, Japan

Full list of author information is available at the end of the article
}

another member of CADM family proteins expressed in the lung, was abrogated in the tumors but not in the normal epithelia. These results suggest that the disruption of the CADM-4.1 cascade of cell adhesion is prerequisite to lung tumor formation.

\section{Author details}

'Division of Molecular Pathology, Institute of Medical Science, The University of Tokyo, Tokyo, Japan. ${ }^{2}$ Division of Pathology, National Institute of Health Sciences, Tokyo, Japan.

Published: 24 September 2010

\section{doi:}

Cite this article as: Nagata et al: Spontaneous development of lung adenocarcinoma in the CADM1 gene-deficient mice. BMC Proceedings 2010 4(Suppl 2):018.

\section{Submit your next manuscript to BioMed Central and take full advantage of: \\ - Convenient online submission \\ - Thorough peer review \\ - No space constraints or color figure charges \\ - Immediate publication on acceptance \\ - Inclusion in PubMed, CAS, Scopus and Google Scholar \\ - Research which is freely available for redistribution

